\title{
UNDERSTANDING THE UK ECONOMY
}




\section{MACMILLAN TEXTS IN ECONOMICS}

This series presents a new generation of economics textbooks from Macmillan developed in conjunction with a panel of distinguished editorial advisers:

David Greenaway, Professor of Economics, University of Nottingham Gordon Hughes, Professor of Political Economy, University of Edinburgh David Pearce, Professor of Economics, University College London

David Ulph, Professor of Economics, University College London

Published

Understanding the UK Economy (3rd edition): edited by Peter Curwen

Business Economics: Paul R. Ferguson, Glenys J. Ferguson and R. Rothschild International Finance: Keith Pilbeam

The Economics of the Labour Market: David Sapsford and Zafiris Tzannatos

Future Macmillan Texts in Economics cover the core compulsory and optional courses in economics at first-degree level and will include:

Public Sector Economics: Stephen Bailey

Financial Economics: Kevin Dowd

Environmental Economics: Nick Hanley, Ben White and Jason Shogren

Development Economics: Ian Livingstone

Econometrics: Ian D. McAvinchey

International Trade: Mia Mikic

Macroeconomics: Eric Pentecost 


\title{
UNDERSTANDING THE UK ECONOMY
}

\section{Third Edition}

Edited by

\section{Peter Curwen}

\author{
Contributors \\ David Gowland and Stephen James \\ Keith Hartley and Nick Hooper \\ Paul Marshall
}

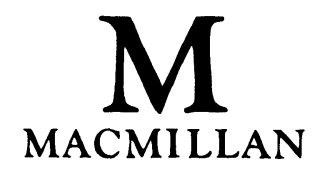


Selection, editorial and Introduction (C) Peter Curwen 1990, 1992, 1994

Individual chapters (C) Peter Curwen (chs 1-9), David Gowland and Stephen James (ch. 12), Keith Hartley and

Nick Hooper (ch. 11), Paul Marshall (ch. 10) 1990, 1992, 1994

All rights reserved. No reproduction, copy or transmission of this publication may be made without written permission.

No paragraph of this publication may be reproduced, copied or transmitted save with written permission or in accordance with the provisions of the Copyright, Designs and Patents Act 1988, or under the terms of any licence permitting limited copying issued by the Copyright Licensing Agency, 90 Tottenham Court Road, London W1P 9HE.

Any person who does any unauthorised act in relation to this publication may be liable to criminal prosecution and civil claims for damages.

First edition 1990

Reprinted 1990

Second edition 1992

Third edition 1994

Published by

THE MACMILLAN PRESS LTD

Houndmills, Basingstoke, Hampshire RG21 2XS

and London

Companies and representatives

throughout the world

ISBN 978-0-333-61526-3 ISBN 978-1-349-13475-5 (eBook)

DOI 10.1007/978-1-349-13475-5

A catalogue record for this book is available

from the British Library.

Copy-edited and typeset by Povey-Edmondson

Okehampton and Rochdale, England

\section{Series Standing Order (Macmillan Texts in Economics)}

If you would like to receive future titles in this series as they are published, you can make use of our standing order facility. To place a standing order please contact your bookseller or, in case of difficulty, write to us at the address below with your name and address and the name of the series. Please state with which title you wish to begin your standing order. (If you live outside the United Kingdom we may not have the rights for your area, in which case we will forward your order to the publisher concerned.)

Customer Services Department, Macmillan Distribution Ltd, Houndmills, Basingstoke, Hampshire, RG21 2XS, England 
To Benjamin and Alexandra 


\section{Contents}

List of Figures

List of Tables

List of Abbreviations

Preface to the First Edition

Preface to the Second Edition

Preface to the Third Edition

Acknowledgements

\section{Chapter 1: History and Politics}

Peter Curwen

1.1 Introduction

1.2 The Neo-classical World

1.3 The Keynesian Revolution

1.4 Efficiency versus Equity

1.5 Employment, Trade and Inflation

1.6 The Brief Reign of Monetarism

1.7 The Thatcher Years, 1979-90

1.8 The Political Context

Chapter 2: The Macroeconomy: 1

Peter Curwen

2.1 Introduction

2.2 The Internal Sector

2.3 Money Supply and the Supply Side

2.4 The External Sector

2.5 The Multiplier

2.6 Crunchy Numbers

2.7 Introduction to National Income Accounting

2.8 The National Accounts

2.9 Sectoral Surpluses and Deficits

2.10 Income and Wealth

2.11 The Housing Market

Chapter 3: The Macroeconomy: 2

Peter Curwen

3.1 Personal Income, Consumption and Saving

3.2 Investment
$\mathbf{X}$

xiii

xvi

xix

xxi

xxii

xxiii

$\begin{array}{llll}1 & 3.3 & \text { Stocks } & 62\end{array}$

3.4 Capacity Utilisation 63

$13.5 \quad$ Company Profitability 64

$2 \quad 3.6$ Growth and Productivity 66

$\begin{array}{llll}4 & 3.7 & \text { Inflation } & 74\end{array}$

$\begin{array}{llll}6 & 3.8 & \text { Credit Crunch } & 88\end{array}$

$8 \quad 3.9$ Is There a Business Cycle? 90

113.10 Supply-side Economics 91

13 Appendix: Say's Law, the Laffer Curve

14 and the Gutman Effect 93

18 Chapter 4: The Financial System 96

Peter Curwen

$184.1 \quad$ Financial Intermediation 96

$194.2 \quad$ Classifying Financial Intermediaries 97

214.3 The Bank of England 98

22 4.4 Banks in the UK 102

$24 \quad 4.5 \quad$ Non-bank Financial Intermediaries 116

$25 \quad 4.6 \quad$ Money Markets 124

4.7 Capital Markets 128

$25 \quad 4.8 \quad$ 'Big Bang' and its Aftermath 132

$\begin{array}{llll}26 & 4.9 & \text { Investor Protection } & 133\end{array}$

354.10 Financial Intermediation

39 in the Future 136

$\begin{array}{llll}40 & 4.11 & \text { Conclusion } & 141\end{array}$

49 Chapter 5: Spending, Taxing and

Borrowing

Peter Curwen

$49 \quad 5.1 \quad$ Introduction 143

$58 \quad 5.2$ Public Expenditure 143 
5.3 The Overall Tax Burden

5.4 Fiscal Drag

5.5 International Comparisons

5.6 The Tax System

5.7 The Budget

5.8 The Public Sector Borrowing

Requirement and Public Sector Debt

Repayment

5.9 The National Debt

Chapter 6: External Transactions

Peter Curwen

6.1 Introduction

6.2 The System of Balance of Payments Accounts

6.3 The Structure of the Accounts

6.4 The Accounts in Retrospect

6.5 International Perspectives

6.6 Direct Investment

6.7 Competitiveness

6.8 Area Composition of UK Visible Trade

6.9 Commodity Composition of UK Visible Trade

6.10 Exchange Rates

6.11 Exchange Rate Issues

6.12 The International Monetary System

6.13 The International Debt Crisis

\section{Chapter 7: External Relations}

Peter Curwen

7.1 Introduction

7.2 The Single European Market

7.3 The Community Budget and the UK

7.4 The European Monetary System (EMS)

7.5 Economic and Monetary Union (EMU) and European Political Union (EPU)

7.6 The Demise of Free Trade?

7.7 Protection

7.8 1992 and EU Trade

7.9 Subsidies

7.10 The General Agreement on Tariffs and Trade (GATT)

7.11 Agriculture

7.12 Negotiations at the GATT
155

157

158

159

174

177

180

184

184

185

186

189

203

204

208

210

213

216

227

227

230

234

234

234

240

245

251

260

262

264

265

266

271

282
Chapter 8: Employment and

Unemployment

Peter Curwen

8.1 Introduction

287

8.2 Employment 288

8.3 Unemployment

298

Chapter 9: The Labour Market

Peter Curwen

9.1 Education and Training 323

9.2 Trade Unions

9.3 Recent Labour Market

348

9.4 The European Dimension

350

Chapter 10: Welfare: Inequality

and Poverty

Paul Marshall

10.1 Inequality and Income Distribution 353

10.2 The Concentration of Wealth

363

10.3 Poverty and Income Maintenance 368

10.4 The Response from the System 375

10.5 A European Perspective

383

Chapter 11: Industry and Policy

Keith Hartley and Nick Hooper

11.1 Introduction: The Policy Issues 391

11.2 Theory and Industrial Policy

394

11.3 The Economics of Regulation and

403

11.4 Competition Policy 406

11.5 Ownership 416

11.6 Subsidy Policy 421

11.7 Public Purchasing $\quad 428$

11.8 Conclusion 434

Chapter 12: Macroeconomic Policy

David Gowland and Stephen James

12.1 Introduction 436

12.2 Macroeconomic Policy 437

12.3 A Framework for Analysis 441

12.4 Methods of Monetary Control 445

12.5 Monetary Policy in the UK, 1971-93 453

12.6 The 1950s and 1960s: The Age of

455

12.7 The 1970s 456

12.8 The 1980s: The Thatcher Years 460 
12.9 The Policy in Action

12.10 Majorism

12.11 The Decline of Keynesianism

12.12 Friedman's Critique

12.13 New Classical and Radical Critiques

12.14 Financial Policy in the Ascendent

12.15 The Desirability of Intermediate Targets
$464 \quad 12.16$ Broad and Narrow Money 488

47412.17 Direct Controls on Credit 489

47812.18 Are Budget Surpluses Beneficial? 490

47912.19 An Independent Central Bank 491

48112.20 Unbalanced Policy 492

483

$487 \quad$ Index

495 


\section{List of Figures}

Figure 2.1 The Internal Sector: Demand

Figure 2.2 Money Supply and the Supply Side

Figure 2.3 The External Sector

Figure 2.4 The Multiplier

Figure 2.5 Financial Surplus/Deficit, by Sector

Figure 2.6 Stock of Dwellings by Tenure, UK, 1963-92

Figure 2.7 Total Cost of Mortgage Interest Tax Relief, UK

Figure 2.8 Personal Sector: Income and Capital Gearing

Figure 2.9 House Transactions

Figure 2.10 Real and Nominal House Price Growth

Figure 2.11 House Price:Earnings Ratio

Figure 2.12 Percentage Deviation of Regional House Prices from the National Average since 1983

Figure 2.13 The Evolution and Possible Development of Negative Equity

Figure 3.1 Personal Income, 1980-93, Quarterly at 1985 Prices

Figure 3.2 Consumers' Expenditure at Constant Prices, by Selected Item, UK, 1974-93

Figure 3.3 The Personal Saving Ratio, 1958-93

Figure 3.4 Consumer Credit, Amount Outstanding, Great Britain, 1982-90

Figure 3.5 New Borrowing, Net of Repayments

Figure 3.6 UK Retail Sales

Figure 3.7 Growth Rates and Investment Ratios, OECD, 1979-90
Figure 3.8 Business Investment as \% of GDP 62

Figure 3.9 Stock:Output Ratio

63

Figure 3.10 Capacity Utilisation

Figure 3.1

Companies' Real Rates of Return on Capital, Pre-tax, 1970-92

Figure 3.12 Net Operating Surplus as a Proportion of the Net Capital Stock: Business Sector

Figure 3.13 GDP

Figure 3.14 Average Growth for Six-year Periods, $1949-54$ to $1983-87$

Figure 3.15 Output and Productivity, UK, 1975-86

Figure 3.16 Ouput and Productivity, UK, 1985-93

Figure 3.17 Structure of the RPI 75

Figure 3.18 RPI

Figure 3.19 Housing, Selected Components of the RPI

Figure 3.20 Official Measures of Inflation, 1987-93

Figure 3.21 Change in Consumer Prices, EU Comparison, 1981-91

Figure 3.22 Consumer Price Indices, Selected Countries, 1978-93

Figure 3.23 The Phillips Curve

51 Figure 3.24 Earnings and Output per Head: Manufacturing Industries

Figure 3.25 Output Gap: Deterministic Trend Measure

Figure 3.26 Financial Crisis and Credit Crunch

Figure 3.27 Company Insolvencies

Central Bank Independence and Inflation/Unemployment 
Figure 4.3 Provisions and Write-offs in Large British Banks

Figure 4.4 UK Pensions: Social Security Cost if Benefits are Linked to RPI

Figure 4.5 Aggregate Turnover on the London Derivative Exchanges

Figure 4.6 Stock of Outstanding Euronotes

Figure 4.7 ECU Bond Market: Volume Outstanding

Figure 4.8 The Capital Markets

Figure 4.9 The USM

Figure 4.10 The Framework for Financial Regulation in the UK

Figure 5.1 The NCT and GCE: How it is Planned and Spent, 1992-93

Figure 5.2 Planning Total and New Control Total in Real Terms

Figure 5.3 General Government Expenditure as \% of GDP, 1890-1996

Figure 5.4 GGE on Services by Function, \% Share of Total, 1980/1981 to $1992 / 93$

Figure 5.5 Taxes and Social Security Contributions

Figure 5.6 Corporation Tax Receipts

Figure 5.7 Taxes and Social Security Contributions as a \% of GNP at Factor Cost, 1990

Figure 5.8 Marginal Tax Rates, 1993-94

Figure 5.9 Sources of Revenue, 1993-94

Figure 5.10 PSBR as a \% of GDP

Figure 5.11 Measures of Public Sector Debt in Relation to GDP

Figure 5.12 General Government Debt Interest Payments

Figure 6.1 UK Share of World Trade in Manufactures

Figure 6.2 Current Balance as \% of GDP

Figure 6.3 Visible Trade Deficit

Figure 6.4 Import Penetration

Figure 6.5 Invisibles Trade Balance

Figure 6.6 Invisibles Balance, 1972-92, \% of Money GDP at Factor Cost

Figure 6.7 Current Account Balances as $\%$ GNP/GDP
Figure 6.8 Contributions to the Change in UK Net External Assets

206

Figure 6.9 Measures of UK Trade

Competitiveness

209

Figure 6.10 Relative Export Performance

Figure 6.11 Visible Trade Balance, Current Prices

211

215

Figure 6.12 Major Centres: Average Net Daily Turnover

Figure 6.13 Sterling ERI, 1974-93, Quarterly Averages

Figure 6.14 EERs

223

223

231

Figure 6.16 Secondary Market Bank Debt Prices

Figure 7.1 Community Legislative Process: New Cooperation Procedure

Figure 7.2 Percentage Share of Directives Incorporated into National Legislation as of 8 December 1992

238

Figure 7.3 Community Budget, 1992

Figure 7.4 1992 Budget Commitments and Resources

Figure 7.5

DM per $£, 1980-90$

250

251

259

Figure 7.7 Sterling Against the DM

Figure 7.8 World Merchandise by

Volume, Annual percentage

Change

262

Figure 7.9 Industrialised Countries, Average Tariffs

267

Figure 7.10 Prices in the CAP

275

Figure 7.11 EU Spending on Agriculture

281

Figure 8.1

Civilian Labour Force of Working Age and Population of Working Age by Sex, Great Britain

Figure 8.2 Population of Working Age, by Sex and Economic Status, UK

Figure 8.3 Trend to Part-time Labour

Figure 8.4 Temporary Workers, \% of Total Employment, 1991

Figure 8.5 Workforce and Workforce in Employment, UK, Seasonally Adjusted 
Figure 8.6 Unemployment and Vacancies, UK, 1971-93

Figure 8.7 Unemployment Rate, Annual Averages, UK

Figure 8.8 The Unemployment Pool

Figure 8.9 UK Unemployment Flows, February 1992-July 93

Figure 8.10 The Monthly Claimant Court Compared with the ILO Measure of Unemployment, Spring 1991, Great Britain

Figure 8.11 Comparisons of Alternative Measures of Unemployment, UK

Figure 8.12 Unemployment by Age, Duration and Sex, April $1993 \quad 308$

Figure 8.13 Regional Unemployment

Figure 8.14 Unemployment Rates, International Comparisons, 1972-93

304

305

Figure 9.1 Employees Receiving Training

Figure 9.2 Expectations of Skill Shortages, Great Britain, 1975-92

Figure 9.3 Trade Unions: 1900-91

Figure 9.4 Year on Year Changes in Employees in Employment and Trade Union Membership

Figure 9.5 Membership and Number of Unions by Size, 1991

Figure 10.1 Hypothetical Lorenz Curves and the Measurement of Inequality

Figure 10.2 Measuring the Gini Coefficient from the Lorenz Curve 356
Figure 10.3 Comparison of Wealth Distribution with and without Property Values, 1976 and 1989

Figure 10.4 Changes in the Number of Poor Persons in the Community, 1980-85

Figure 10.5 Percentage of Poor Community Households Located in Each Member Country

Figure 10.6 Community Anti-poverty Programme

Figure 11.1 Mergers, Scale Economies and Competition

Figure 11.2 Linkages in the Political Market: the Example of Smoking

Figure 11.3 Classifying Privatisation

Figure 11.4 Ownership and Market Structure: A Taxonomy

Figure 11.5 The Economics of Collaboration

Figure 12.1 Relationships between the Monetary Aggregates and their Components

Figure 12.2 The Effect of the Exchange Rate on the Economy

Figure 12.3 Bank Base Rates, 1977-93 466

341 Figure $12.4 \mathrm{AD}$, AS and Inflation 480

Figure 12.5 AD, AS and Phillips Curves 482

Figure 12.6 Alternative Approaches to Credit Control 


\section{List of Tables}

Table 2.1 1992 National Product, Expenditure-based, at Current Prices

Table 2.2 1992 GDP, Income-based, at Current Factor Cost

Table 2.3 GDP at Constant Factor Cost: Output-based Measure, Index Numbers of Output by Sector

Table 2.4 UK GDP by Industry, 1992

Table 2.5 GDP, Growth of Ouput by Sector, 1980-92

Table 2.6 UK Real Domestic Product by Category of Expenditure at 1990 Prices, 1979-92

Table 2.7 Personal Sector: Financial Account, Main Changes, 1986-92

Table 2.8 Mortgage Lenders: Number of Mortgages, Arrears and Possessions, UK

Table 3.1 Share of Total Household Expenditure at Current Prices, UK

Table 3.2 Personal Income, Expenditure and Saving, 1985-92

Table 3.3 Composition of Consumer Credit, UK, 1984-92

Table 3.4 Investment (GDCF) by Type of Asset and by Sector as \% of GDP, at Market Prices, 1979-92

Table 3.5 Investment by Type of Asset as $\%$ of GDFCF, 1979-92

Table 3.6 Output per Person Employed, Average Annual Percentage Changes

Table 3.7 Manufacturing Industry, 1979-87
Table 3.8 GDP/GNP Growth in the Major Six 74

29 Table 3.9 Assorted Price Indices

Table 3.10 Contributions to Output Prices in Manufacturing from Changes in Cost Components

Table 3.11 Index of Wage Costs per Unit of Output

32 Table 3.12 Unit Labour Costs in Manufacturing

33 Table 4.1 Banks in the UK, Deposit Liabilities at 30 December 1992

Table 4.2

Retail Banks: Balance Sheet

Table 4.3 Bank Results 1992

112

Table 4.4 Foreign Banks in London 114

Table 4.5

Building Society Statistics

Table 4.6

Building Societies: Assets and Liabilities, 1992, Quarter 4

Table 4.7

Unit Trust Index

Table 4.8 Foreign Securities' Houses in London

Table 4.9

Disclosure Regimes

Table 5.1 Public Expenditure Totals

146

53 Table 5.2 Public Expenditure, 1971-72 to 1995-96

55 Table 5.3 Total Public Expenditure (as \% GDP), 1974-94

Table 5.4 Increase in Real Expenditure by Function

Table 5.5

Taxes and Social Security Contributions as a \% of GDP

Table 5.6 The Structure of the UK Tax System since 1948

Table 5.7

NICs, 1994-95

Table 5.8

North Sea Revenues

LA Revenues, 1991-94 
Table 5.10 VAT Rates Applied in the Community Member States $(\%)$

Table 5.11 Direct Effects of Budget Measures, Spring 1993

Table 5.12 Borrowing Requirements of Central Government (CGBR) and Public Sector (PSBR)

Table 5.13 General Government Lending or Borrowing as a $\%$ of GDP, 1974-93

Table 6.1 UK BoP Accounts, 1987-92

Table 6.2 Index Numbers, UK Visible Trade

Table 6.3 UK Official Reserves, 1975-92, End-year Values

Table 6.4 BoP of the UK, 1979-92

Table 6.5 Area Composition of UK Exports, f.o.b., 1955-92, $\%$ Total Value

Table 6.6 Area Compostion of UK Imports, c.i.f., 1955-92, $\%$ Total Value

Table 6.7 Commodity Analysis of Exports, \% Total Value

Table 6.8 Commodity Analysis of Imports, \% Total Value

Table 6.9 Selected Sterling Exchange Rates and Effective Exchange Rate Index (ERI), 1975-92, Annual Averages

Table 7.1 Enlarging the Community

Table 7.2 General Government Transactions with the Institutions of the EU

Table 7.3 Community Budget Plans

Table 7.4 The Composition of an ECU

Table 7.5 Central Parity Realignments within the EMS, 1979-90

Table 7.6 EMU Convergence Criteria, 1993

Table 7.7 State Aid to the Manufacturing Sector: Annual Averages, 1988-90 and 1986-88

Table 7.8 Anti-dumping and Countervailing Duty Cases

Table 7.9 EU Agricultural Statistics, 1991

Table 7.10 UK and EU Intervention

Stocks

174

176

195

196

211

212

213

214

222

237

241

244

246

248

254

265

270

274
Table 7.11 Effect of Agricultural Programmes on Domestic Farm Prices, 1980-82 Average and 1988

Table 7.12 Producer Subsidy Equivalents

Table 7.13 Government Support for Agriculture, 1992

280

Table 8.1 Population, UK, 1951-2011 and Great Britain, 1971-2001

Table 8.2 Economic Activity Rates: By Sex, EU Comparison, 1990

Table 8.3 Average Hours Usually Worked per Week, by Sex, EU Comparison, 1990

Table 8.4 Employees in Employment, by Industry, UK

Table 8.5 Employment: By Sex and Full/ Part Time, UK

Table 8.6 Growth of Employment, 1984-90

Table 8.7 Changes in the Methods of Recording Unemployment Statistics, 1979-89

Table 8.8 Long-term Unemployment in Great Britain

Table 8.9 Standardised Unemployment Rates

Table 8.10 The Causes of Male Unemployment in the UK

Table 8.11 NAIRU Estimates for the UK

Table 9.1 Training Expenditure

Table 9.2 Employment and Training Schemes, Great Britain, 1975-76 to 1992-93

Table 9.3 Training for Work: Expenditure and Performance, England

Table 9.4 Major Union Mergers

Table 9.5 Union Density in the UK, Spring 1991

Table 9.6 Stoppages in Progress, UK, 1970-92

Table 10.1 Cumulative Distribution of Personal Income before Tax, UK, 1949-85 
Table $10.2 \%$ Shares of Main

Components in Total

Household Income,

UK, 1971-91

Table 10.3 Cumulative Distribution of

Personal Income after Income

Tax, UK, 1949-85

Table 10.4 Household Definitions used by

$\mathrm{CSO}$ in Estimates of Income

Distribution

Table 10.5 Cumulative Distribution of

Original, Disposable and Final

Household Income,

UK, 1976-86

Table 10.6 Cumulative Distribution of

'Equivalised' Incomes,

UK, 1977-90

Table 10.7 The Distribution of Marketable Wealth in Great

Britain, 1911-60, and the UK, 1966-90

Table 10.8 Estimate of Numbers below SB Level, 1972-87

Table 10.9 Projections of the Elderly Population, UK and Selected Countries

Table 10.10 Estimates of SB Take-up

Table 10.11 Poverty among Children and the Elderly in the Community
Table 10.12 Community Poverty Incidence, 1980 and 1985

385

Table 11.1 Contribution to GDP by Sector

392

360

Table 11.2 Employment, Productivity and External Trade

393

Table 11.3 A Taxonomy of Industrial Policy

397

Table 11.4 Major Competition Policy Measures

407

361 Table 11.5 Firm Size and Market Structures

411

Table 11.6 UK Privatisations

418

Table 11.7 DTI Programmes

423

362

Table 11.8 Government Spending on Science and Technology

Table 12.1 GDP, Inflation and

426

363 Unemployment, 1950-79, Selected Years

Table 12.2 Monetary Targets and Outcomes, 1976-79

Table 12.3 MTFS, Target Ranges and Outcomes

Table 12.4 The Performance of the Economy, 1979-88

Table 12.5 The Lawson Boom: Selected Indicators, 1985-88

Table 12.6 Representative Money Market Interest Rates

Table 12.7 Into Recession, 1989-91

Table 12.8 Stabilisation Policy 


\section{List of Abbreviations}

\begin{tabular}{|c|c|c|c|}
\hline ACT & Advance Corporation Tax & EEA & Exchange Equalisation Account \\
\hline $\mathrm{AD}$ & Aggregate Demand & EEC & European Economic Community \\
\hline \multirow[t]{2}{*}{ AFBD } & Association of Futures Brokers and & EER & Effective Exchange Rate \\
\hline & Dealers & EFF & Extended Fund Facility \\
\hline AMS & Aggregate Measure of Support & $\mathrm{EFL}$ & External Financing Limit \\
\hline $\mathrm{APC}$ & Average Propensity to Consume & EFTPOS & Electronic Funds Transfer at Point of \\
\hline AS & Aggregate Supply & & Sale \\
\hline ATM & Automated Teller Machine & EMCF & European Monetary Co-operation \\
\hline $\mathrm{BBC}$ & British Broadcasting Corporation & & Fund \\
\hline BES & Business Expansion Scheme & EMI & European Monetary Institute \\
\hline BIS & Bank for International Settlements & EMS & European Monetary System \\
\hline BoP & Balance of Payments & EMTNs & Euromedium-term Notes \\
\hline \multirow[t]{2}{*}{ BTEC } & Business and Technician Education & EMU & Economic and Monetary Union \\
\hline & Council & EPU & European Political Union \\
\hline CAP & Common Agricultural Polcy & ERI & Effective Exchange Rate Index \\
\hline CBI & Confederation of British Industry & ERM & Exchange Rate Mechanism \\
\hline $\mathrm{CCC}$ & Competition and Credit Control & ESCB & European System of Central Banks \\
\hline $\mathrm{CD}$ & Certificate of Deposit & ET & Employment Training \\
\hline CET & Common External Tariff & EU & European Union \\
\hline CFSP & Common Foreign and Security Policy & FES & Family Expenditure Survey \\
\hline CGT & Capital Gains Tax & FIMBRA & Financial Intermediaries, Managers \\
\hline CR & Concentration Ratio & & and Brokers Regulatory Association \\
\hline CSE & Consumer Subsidy Equivalent & FIS & Family Income Supplement \\
\hline $\mathrm{CSO}$ & Central Statistical Office & FMI & Financial Management Initiative \\
\hline CTT & Capital Transfer Tax & FRN & Floating-rate Note \\
\hline DCE & Domestic Credit Expansion & FSBR & Financial Statement and Budget \\
\hline \multirow[t]{2}{*}{ DHSS } & Department of Health and Social & & Report \\
\hline & Security & GAB & General Agreements to Borrow \\
\hline DIB & Defence Industrial Base & GATT & General Agreement on Tariffs and \\
\hline $\mathrm{DM}$ & Deutsche Mark & & Trade \\
\hline DTI & Department of Trade and Industry & GCSE & General Certificate in Secondary \\
\hline \multirow[t]{2}{*}{ EAGGF } & European Agricultural Guarantee and & & Education \\
\hline & Guidance Fund & GDFCF & Gross Domestic Fixed Capital \\
\hline EAP & Enlarged Access Policy & & Formation \\
\hline EAS & Enterprise Allowance Scheme & GDP & Gross Domestic Product \\
\hline EC & European Community & GEMM & Gilt-edged Market-maker \\
\hline $\mathrm{ECB}$ & European Central Bank & GGE & General Government Expenditure \\
\hline ECU & European Currency Unit & GNP & Gross National Product \\
\hline EDI & Electronic Data Interchange & HBAI & Households Below Average Income \\
\hline
\end{tabular}




\begin{tabular}{|c|c|c|c|}
\hline HMSO & Her Majesty's Stationery Office & NDP & Net Domestic Product \\
\hline IBELs & Interest-bearing Eligible Liabilities & NHS & National Health Service \\
\hline \multirow[t]{2}{*}{ ICCs } & Industrial and Commercial & NI & National Income \\
\hline & Companies & NICs & National Insurance Contributions \\
\hline IDC & Industrial Development Certificate & NIESR & National Institute for Economic and \\
\hline IFA & Independent Financial Adviser & & Social Research \\
\hline IFS & Institute for Fiscal Studies & NNP & Net National Product \\
\hline IGA & Inter-governmental Agreement & NSB & National Savings Bank \\
\hline IGC & Inter-governmental Conference & OECD & Organisation for Economic Co- \\
\hline ILO & International Labour Office & & operation and Development \\
\hline IMF & International Monetary Fund & OFGAS & Office of Gas Supply \\
\hline \multirow[t]{2}{*}{ IMRO } & Investment Management Regulatory & OFT & Office of Fair Trading \\
\hline & Organisation & OFTEL & Office of Telecommunications \\
\hline IPD & Interest, Profits and Dividends & OMO & Open-market Operation \\
\hline IPR & Intellectual Property Right & OPEC & Organisation of Petroleum Exporting \\
\hline \multirow[t]{2}{*}{ ISDA } & International Swap Dealers & & Countries \\
\hline & Association & OTC & Over the Counter \\
\hline JA & Jobseeker's Allowance & PAYE & Pay As You Earn \\
\hline LA & Local Authority & PDI & Personal Disposable Income \\
\hline \multirow{2}{*}{ LASFE } & Local Authority Self-financed & PEP & Personal Equity Plan \\
\hline & Expenditure & PIA & Personal Investment Authority \\
\hline \multirow[t]{2}{*}{ LAUTRO } & Life Assurance and Unit Trust & PIBS & Permanent Interest Bearing Shares \\
\hline & Regulatory Organisation & PPP & Purchasing Power Parity \\
\hline LDC & Less Developed Country & PPS & Perpetual Preferred Stock \\
\hline LDMA & London Discount Market Association & PRT & Petroleum Revenue Tax \\
\hline LFS & Labour Force Survey & PSBR & Public Sector Borrowing Requirement \\
\hline LIBOR & London Inter-bank Offered Rate & PSDR & Public Sector Debt Repayment \\
\hline LIF & Low Income Families & PSE & Producer Subsidy Equivalent \\
\hline \multirow[t]{2}{*}{ LIFFE } & London International Financial & $\mathrm{R} \& \mathrm{D}$ & Research and Development \\
\hline & Futures Exchange & RDG & Regional Development Grant \\
\hline LSE & London Stock Exchange & REG & Regional Enterprise Grant \\
\hline LTOM & London Traded Options Market & RER & Real Exchange Rate \\
\hline MCA & Monetary Compensatory Amount & RPI & Retail Prices Index \\
\hline MFA & Multi-fibre Arrangement & RPIX & Underlying Retail Prices Index \\
\hline MIPs & Mortgage Interest Payments & RPM & Resale Price Maintenance \\
\hline MIRAS & Mortgage-interest Relief at Source & RSA & Regional Selective Assistance \\
\hline MLR & Minimum Lending Rate & $\mathrm{SB}$ & Supplementary Benefit \\
\hline \multirow[t]{2}{*}{ MMC } & Monopolies and Mergers & SDR & Special Drawing Right \\
\hline & Commission & SEA & Single European Act \\
\hline MoD & Ministry of Defence & SEAQ & Stock Exchange Automated \\
\hline MPW & Marginal Propensity to Withdraw & & Quotation \\
\hline MSC & Manpower Services Commission & SEM & Single European Market \\
\hline MTFS & Medium Term Financial Strategy & SERPS & State Earnings Related Pension \\
\hline MTN & Multilateral Trade Negotiations & & Scheme \\
\hline \multirow[t]{2}{*}{ NAIRU } & Non-accelerating Inflation Rate of & SFA & The Securities and Futures Authority \\
\hline & Unemployment & SFF & Supplementary Financing Facility \\
\hline NBFI & Non-bank Financial Intermediaries & SIB & Securities and Investments Board \\
\hline NCT & New Control Total & SMU & Support Measurement Unit \\
\hline
\end{tabular}




$\begin{array}{llll}\text { SRO } & \text { Self Regulatory Organisation } & \text { YTS } & \text { Youth Training Scheme } \\ \text { TB } & \text { Treasury Bill } & \\ \text { TDI } & \text { Total Domestic Income } & \text { Countries are abbreviated in tables and figures in } \\ \text { TEC } & \text { Training and Enterprise Council } & \begin{array}{l}\text { accordance with the originals. The following ab- } \\ \text { TESSA }\end{array} & \text { Tax Exempt Special Savings Account } \\ \text { TFE } & \text { Total Final Expenditure } & \text { breviations are used: } \\ \text { TPI } & \text { Tax and Price Index } & \text { Belgium } & \text { B } \\ \text { TRS } & \text { Transitional Reduction Scheme } & \text { Denmark } & \text { DK } \\ \text { TSA } & \text { The Securities Association } & \text { France } & \text { F or FR } \\ \text { TSB } & \text { Trustee Savings Bank } & \text { Greece } & \text { GR } \\ \text { UAA } & \text { Utilised Agricultural Area } & \text { Ireland } & \text { IRL } \\ \text { USM } & \text { Unlisted Securities Market } & \text { Italy } & \text { I or IT } \\ \text { VAT } & \text { Value Added Tax } & \text { Luxembourg } & \text { L } \\ \text { VER } & \text { Voluntary Export Restraint } & \text { Netherlands } & \text { NL } \\ \text { VSTF } & \text { Very-short-term Financing } & \text { Portugal } & \text { P } \\ \text { WIRS } & \text { Workplace Industrial Relations } & \text { Spain } & \text { S or E } \\ & \text { Survey } & \text { United Kingdom } & \text { UK } \\ \text { YES } & \text { Youth Employment Subsidy } & \text { West Germany } & \text { FRG or WG or D } \\ \text { YOP } & \text { Youth Opportunity Programme } & \text { FR } & \end{array}$




\section{Preface to the First Edition}

We very much hope that the justification for writing a book of this kind is self-evident. If this is not the case, then we simply wish to point out that economic literacy remains at far too low a level in the UK. In seeking to enhance this literacy we like to think that this book will be of interest to a very wide-ranging audience, but we recognise that, in practice, almost all those who read it will be studying a parallel course in economic principles, either at A-level or as undergraduates, or will already be acquainted with economic issues either through their work or their reading of the financial press. We hope that the book is sufficiently challenging to interest readers who are already conversant with economics, but not so challenging as to prevent readers who are not conversant with economic theory from following the discussion.

We have tried to strike an acceptable balance between analysis and description. It is obviously necessary, in a book of this kind, to describe how the UK functions at the present time, and also how it has functioned in the past where this has been different. It is, however, unilluminating simply to explain what is done in policy terms without simultaneously explaining why, and the reasons why are also to be found in the book where appropriate. It should be noted that the kinds of models to be found in textbooks may often fail to explain why many policies are being pursued, because the real world may be evolving very rapidly and be using fairly crude rules of thumb whilst coming to terms with these changes. It is accordingly our intention to concentrate upon the real world, and to give short shrift to textbook models which cannot shed much light upon it.

Most readers familiar with economics will have been taught the subject as a succession of separate boxes labelled 'employment', 'inflation', and so on. There is, as a consequence, a preference for applications to be organised into similar boxes, to be dipped into one by one as appropriate. We do not care for this approach because, first, it fails to emphasise the fundamental linkages between the various parts of the economy; secondly, it fails to deliver a satisfactory historical perspective; and thirdly, it permits the authors covering the content of separate boxes to offer a subjective interpretation of events which conflicts with that to be found in other boxes. Rather oddly, some books consider this latter point to be a virtue, and express distaste for the imposition of monolithic structures. Our view is that this is very much a vice, and indicative of lack of editorial control. This book is accordingly approached from precisely the opposite viewpoint - namely, that individual authors should work to a carefully predetermined structure and that stylistic differences should be kept to a minimum. In particular, each author has been asked to set out the pros and cons of every policy debate without prejudice. This does not mean that the authors do not have strong preferences concerning the conduct of policy, nor indeed that they have refrained from expressing them, but rather that they do not seek to persuade by omitting to mention what the counter-arguments are.

The issue concerning the need to provide a framework which integrates individual sections has been difficult to resolve. One innovative feature in this respect is the introductory chapter which seeks to provide both a philosophical basis and an historical perspective for all that follows. A second innovation is to set the discussion of fiscal and monetary policy at the end of the book, in Chapter 12, so that it draws together the macroeconomic threads from previous chapters, with Chapter 11 doing the same for the microeconomic threads. The early chapters presume least prior knowledge, but when necessary they are exten- 
sively cross-referenced to later points in the text where the missing information is to be found. Issues which can be broadly be said to concern welfare have been allocated a chapter of their own (Chapter 10), rather than ignored altogether or dispersed in brief and unrelated sections throughout the text.

Certain themes inevitably appear under several chapter headings - for example, the development of the Single European Market (SEM). Generally speaking they are left dispersed, but cross-referenced to other parts of the book where the same themes recur. However, in certain cases - for example, agriculture - it has made more sense to collect the themes together under one heading in order to avoid duplication and the loss of continuity in the discussion. For these reasons, the structure of the book may at first sight appear unusual, but we firmly believe that it does, in fact, make better sense than the structures to be found in other texts, and we leave it to the readers to judge for themselves (and hopefully to let us know their opinions on the matter in due course).

While the book is essentially about the UK economy, it has a stronger international flavour than is commonly associated with books on this topic. This reflects a whole host of developments, such as the SEM and deregulation in general, which are making it increasingly inappropriate to view policy within the physical confines of the UK alone. Since this is very much a feature of ongoing policy we have deliberately set up our discussion so that it offers clear pointers towards the future, and we have chosen to compensate for this by saying much less than is usual about the more distant past.

In our opinion the election of the current government was a significant watershed in policy terms, for reasons set out in the Introduction. Each chapter is accordingly structured to say relatively little about the period before 1969 ; to provide a fairly detailed review of the decade 1969-79; and to focus primarily upon the decade 1979-89 and especially upon how it has compared with the decade which preceded it.

All this places great demands upon the handling of data. We have tried to introduce as much data as possible, and to locate it all within the appro- priate context rather than relegate it to appendices. Equally, we recognise that tabular material can be boring - and, at times, a poor means of communication - so where appropriate other methods of presentation have been used. A point to be emphasised is that data are expressed in the form normally used by government and reported in the media. Thus, for example, the Public Sector Borrowing Requirement (PSBR) is not simply stated as an absolute number but as a percentage of gross domestic product (GDP). Much of the data is adjusted for inflation, and whenever space permits the comparable data for other countries are also included.

The contributors to this book (other than the editor) have been chosen because they are knowledgeable in their fields. However, too much knowledge can be a vice as well as a virtue when it comes down to the need to compress a great deal of information into a small space, and the authors are commended to you not so much because they are 'specialists' but because they have proved in their previously published work that they have the facility to communicate to the target audience for this book. We hope that it makes enjoyable reading. No doubt you will let us know if that is not the case. One way or the other the editor is more than happy to accept ultimate responsibility for the entire finished product, although individual authors are responsible only for the chapters which bear their name.

Finally I would like to thank Gordon Hughes and the other five anonymous reviewers for their thorough dissection of the text in its varying stages of completion. There is a myth - propagated, one suspects, by those who write only short articles that textbooks are not refereed adequately, but that has been far from the reality in this particular case. Whilst some suggestions for improvements have been set aside for this edition, it is anticipated that they will be incorporated in the second edition.

Any restructuring of the text in subsequent editions will be determined entirely by the suggestions of users, and these are accordingly welcomed by the editor.

Peter CuRWEN 


\section{Preface to the Second Edition}

Armed with reviews and a large number of questionnaires completed by teachers, we have set out to revise the text significantly for this second edition. While not every suggestion for improvement has been adopted on this occasion, we are already considering how best to manage the book's evolutionary path.

It is important to begin by clearing up one particular misunderstanding. Although it is hoped that many readers will be able to enjoy the text without having previously learned economics in a formal way, we anticipated that most readers would use this book in conjunction with a basic text on economic theory, thereby allowing us to concentrate upon its applications in the real world. The text contains such models as are essential to assist both the general reader and students of economics who are reading ahead of their main text to understand the issues which we address, which can be very complicated, but it is simply impractical to try to combine detailed theory and applications in a single text.

We have attempted to keep the text as up to date as is humanly possible. To this end we have introduced a large amount of new data, particularly in the form of Figures, whilst removing a much smaller amount which appeared in the first edition. We believe that this database provides a truly comprehensive overview of the workings of the UK economy. In recognition of recent developments we have included a good deal of additional material on the European Community, and have sought wherever possible to draw comparisons between the performance of the UK and other member states.

The editor has chosen in this edition to take over responsibility for writing all of the first nine chapters in the book, two of which have been divided compared to the first edition as a result of the addition of much new material. This should ensure greater uniformity of approach, and also ease the burden of revision for future editions. The new material is generally intended to introduce developments which have taken place over the past two years, but completely new sections have also been added where it was thought that they would enhance the discussion in a material way. For example, there is a new section devoted to the housing market in Chapter 3, which is accompanied by a fuller discussion of the link between wealth, consumption and saving, and Chapter 2 contains a completely new version of the overall model of the economy.

It is hoped that these, and other, improvements have enhanced the usefulness of the text for a wide variety of readers. As before, the text has been thoroughly reviewed in draft form in order to ensure that this is so, and we would like to thank the reviewers for their extensive and helpful comments.

PETER CURweN 


\section{Preface to the Third Edition}

Only two years have passed since the publication of the second edition, but events have, as ever, refused to stand still, necessitating some significant revisions to parts of the text. Looking back at what was written two years ago, the analysis appears to have held up well and we see no need to retract anything of substance, but there can be no doubt that two years of recession oblige us to rethink the probable course of the UK economy during the rest of the decade.

When the second edition was at final proof stage it proved necessary to insert a substantial section relating to the Maastricht Treaty. At the time it was assumed that it would be signed and sealed before 1992 was out, with member states if anything moving closer together in the narrow band of the Exchange Rate Mechanism (ERM). In the event, the outcome has been rather different, so this edition contains a good deal of analysis of what went wrong and where it is taking the UK.

In this, and other respects which reflect, for example, the official creation of the SEM on 1 January 1992, the text is increasingly seeking to examine the role of the UK as part of a wider political/economic system. Nevertheless, the UK has recently been affected by the consequences of some of its own peculiar structures, and of these the housing market is clearly the most prominent. For this reason, the discussion of the role of the housing market has been greatly extended in this edition.

In most other respects the primary task has been, as usual, to update the database so that it provides a meaningful picture of the current state of the economy; in effect, that prevailing at the end of 1992 or some months into 1993, but any significant turns in events at the end of 1993 have also been integrated into the text. We therefore trust that this new edition will continue to provide teachers and students alike with an invaluable insight into the workings of the UK economy.

One final change of practice needs to be noted. Whereas in previous editions we referred to the European Community (EC), throughout this edition we refer to the European Union (EU), or occasionally simply to the Community, in line with current practice in the majority of governmental and media commentary. In practice, insofar as the terms EC and EU relate to the subject matter of this book, they can be treated as interchangeable.

Peter Curwen 


\section{Acknowledgements}

The authors and publishers wish to thank the following for permission to use copyright material:

Bank of England for Tables 3.8, 3.10, 3.12, 4.2, 4.3, 4.7, 6.3, 8.12 and Figures 2.8, 2.10, 2,11, 2.12, 3.3, $3.5,3.8,3.9,3.11,3.25,3.27,4.3,4.5,4.6,4.7,5.11$, 6.4, 6.8, 6.12, 6.13, 6.14, 6.15, 12.1 .

Barclays Bank for Table 12.6 and Figures 3.26, 12.3.

Confederation of British Industry for Figures 3.10 and 9.2.

The Controller of Her Majesty's Stationery Office for Tables 2.1, 2.2, 2.3, 2.4, 2.5, 2.6, 2.7, 2.8, 3.1, 3.2, 3.3, 3.4, 3.5, 3.9, 3.11, 5.1, 5.2, 5.4, 5.5, 5.7, $5.8,5.9,5.11,5.12,6.1,6.2,6.4,6.5,6.6,6.7,6.8$, $7.6,7.17,8.1,8.2,8.3,8.4,8.5,8.6,8.7,8.8,8.9$, $8.10,9.1,9.3,9.5,9.6,10.1,10.2,10.3,10.4,10.5$, $10.6,10.7,11.1,11.2,11.5,11.8,11.9,12.1,12.3$, 12.4, 12.7; and Figures 2.5, 2.6, 2.7, 2.9, 3.1, 3.2, $3.4,3.6,3.13,3.15,3.16,3.17,3.18,3.19,3.20,3.21$, $3.22,3.23,3.24,5.1,5.2,5.3,5.4,5.5,5.6,5.7,5.10$, $5.12,6.1,6.2,6.3,6.5,6.6,6.9,6.11,7.1,8.1,8.2$, $8.5,8.6,8.7,8.9,8.10,8.11,8.12,8.13,8.14,9.1$, $9.3,9.4,9.5,10.4$.
Council of Mortgage Lenders for Table 4.6.

Financial Times for Table 7.15 and Figures 4.2, $4.4,4.10,7.8,8.3$.

Information Division, HM Treasury, for Table 3.6 and Figure 3.14.

Institute for Fiscal Studies for Tables 10.8, 10.11 and Figure 10.3.

Noel Alexander Associates for Tables 4.5 and 4.9.

Office for Official Publications of the European Communities for Tables 5.3, 5.13, 7.12, 7.16, 10.12, 10.13 and Figures 10.5, 10.6, 10.7.

The Economist for Figures 4.1, 4.9, 6.7, 8.4.

Every effort has been made to trace all the copyright-holders, but if any have been inadvertently overlooked the publishers will be pleased to make the necessary arrangement at the first opportunity. 